\title{
Evidence of Expulsion of Unfertilized Ova into the Vagina in Pseudopregnant Rabbits
}

\author{
Yoshio Tsutsum and Tetsuo Takeda \\ Department of Animal Science, Faculty of Agriculture, Hokkaido \\ University, Sapporo-shi 060
}

(Received April 10, 1976)

\begin{abstract}
Non-surgical recoveries of unfertilized ova were performed for a month after sterile mating in 22 pseudopregnant rabbits by the vaginal flushing technique. Thirtyone degenerative ova and 13 suspected materials which were analogous to the degenerative ova were recovered in 307 vaginal flushings. More than half of ova (52\%) were recovered concentrically on $3^{3}$ to 5 days post coitum, and their remains were obtained dispersedly for a long period beyond the termination of pseudopregnancy. The recovery rate of ova, however, was comparatively higher 18 to 22 days post coitum than that of other periods, except for the first 5 days. The earliest ova were detectable in the vaginal flushing 90 hours post coitum and this suggests that the early maternal recognition of the fertilized eggs may be established prior to 90 hours post coitum in pregnant does. The technique of vaginal flushing was also described.
\end{abstract}

A good proportion of unfertilized and degenerated ova persist in the uterus at least up to the 15th day of pseudopregnancy in the rabbit ${ }^{1}$. Tsursumr et al. ${ }^{2)}$ located unfertilized ova in the uterine horn during pseudopregnancy in a rabbit using the freezing-clearing technique by $O_{R}$ SINI $^{3)}$ and HowE ${ }^{4}$. They found a small number of unfertilized ova remaining in the uterus 17 days post coitum (p.c.). The recovery rate of unfertilized ova in pseudopregnant rabbits was upwards of $50 \%^{1)}$, while the detectability of ova located in the uterine horn was $74 \% 5$ days p.c. and $79 \% 7$ days p.c., respectively2). However, detection of embryos in the reproductive tract was approximately $100 \%$ by the freezing-clearing technique during the preimplantation stage ${ }^{5}$. The lower detectability of the uterine ova in early pseudopregnant stage as compared with that in the preimplantation stage may suggest that some of the unfertilized ova disappear from the uterine lumen.

When fertilized ova were transferred into the oviducts of ovariectomized does treated with estrogen and with vaginal ligation at a portion immediately above the urethro-vaginal septum, $23 \%$ of the ova were recovered from 10 to 78 hours after transfer ${ }^{6}$. With the decreasing numbers of corpora lutea by uni-ovariectomy, the rate of uterine eggs recovered $5 \frac{1}{2}$ days p.c. fell from $83 \%$ ( 8 corpora lutea) to $4 \%$ (no corpora lutea). Failure in the recovery of eggs from the uterus was due to the expulsion of eggs into the vagina, because $45 \%$ of the eggs were recovered from the uterus and $55 \%$ from the ligated vagina in does with two corpora lutea ${ }^{7}$. Similar experiments were conducted by enucleation of early corpora lutea and it was recognized that the correct timing of the entry of eggs into the uterus is vitally important for their further survival. If premature entry of eggs into the uterus occurs, the eggs are quickly transported through the uterus and expelled into the vagina ${ }^{8}$ ), thus, the eggs were often found in the vaginal lumen at autopsy in various experiments. Nevertheless, no trials of non-surgical recovery of eggs from the vaginal lumen have been carried out up to date. As mentioned above, some of the uterine eggs may be ex- 
pected to be expelled into the vagina in the early pseudopregnant stage but the fate of unfertilized ova in the pseudopregnant does remains uncertain. Thus the present study was conducted to recover the unfertilized ova from the vaginal lumen non-surgically to make clear the fate of the eggs during pseudopregnancy.

\section{Materials and Methods}

Vaginal flushings were made in a total of 22 adult Japanese White does. Ovulation was induced by double mating with vasectomized males following $20 \mathrm{IU}$ of hCG injection. The vaginal flushings were repeated on alternate or every day for about one month in each doe. The does were alloted to four groups by the timing of first vaginal flushing; 96 hours p.c. in group 1 ( 6 does), 78 hours p.c. in group 2 (6 does), 84 hours p.c. in group 3 (5 does), and 90 hours p.c. in group 4 (5 does).

The vaginal flushing was carried out using an apparatus with a two-way system (Text-Fig. 1). The fur around the external genitalia was shaved before the experiment. Each doe was secured to a board in a supine position and the external genitalia was disinfected. The apparatus was gently inserted into the vaginal lumen through the vulva up to the caudal cervical portion, then the doe was placed head up on a $40^{\circ}$ slope. Anesthesia was not necessary for the insertion of the apparatus. Flushing fluid amounting to approximately $50 \mathrm{~m} l$ was infused into the upper part of the vaginal lumen through the internal narrow tube and finally recovered through the external tube into $100 \mathrm{ml}$ test tube. The fluid was allowed to settle for $20 \mathrm{~min}$ before approximately $7 \mathrm{~m} l$ were removed from the bottom of the test tube and placed in a watchglass to be examined for ova with a dissecting microscope. Most of the recovered ova were pho-
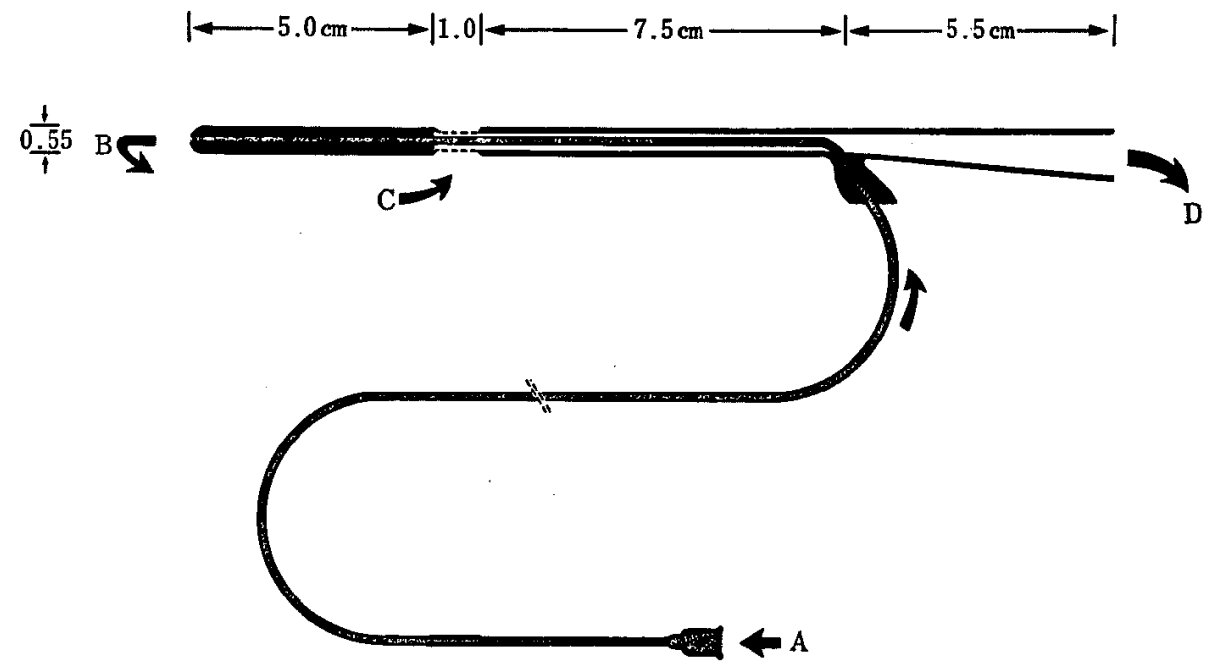

Text-Fig. 1. Diagram of the apparatus used for non-surgical recovery of rabbit ova from the vagina. Warmed flushing fluid is infused into a narrow polyethylene tube by injector (A), the fluid runs out through a catheter to anterior part of the vaginal lumen (B). The washings return to the catheter through holes (C), and are recovered in the test-tube (D). Arrows show the direction of the fluid flow. 
tographed and the diameter was measured using an occular micrometer. The flushing fluid was sterile physiological saline containing $700 \mathrm{IU} / \mathrm{m} l$ of penicllin $\mathrm{G}$ potassium and $500 \mu \mathrm{g} / \mathrm{m} l$ of strepto. mycine sulfate.

\section{Results}

Flushings of 307 in total were made (Table 1). Thirty-one unfertilized and degenerated ova and 13 suspected materials which were analogous to the degenerative ova were found. No ova were recovered in six does (27\%). In the first flushings of groups 2 and 3 , no ova were recovered. The earliest ova were detected in 2 does 90 hours p.c. in group 3. In general, the ova appeared concentrically from 90 hours to 5 days p.c. (52\%), and the remainder $(48 \%)$ were detected dispersedly during the later period, although a higher detec-

Table 1. Numbers of unfertilized and degenerated ova recovered from the vaginal lumen of pseudopregnant rabbits by a vaginal flushing technique

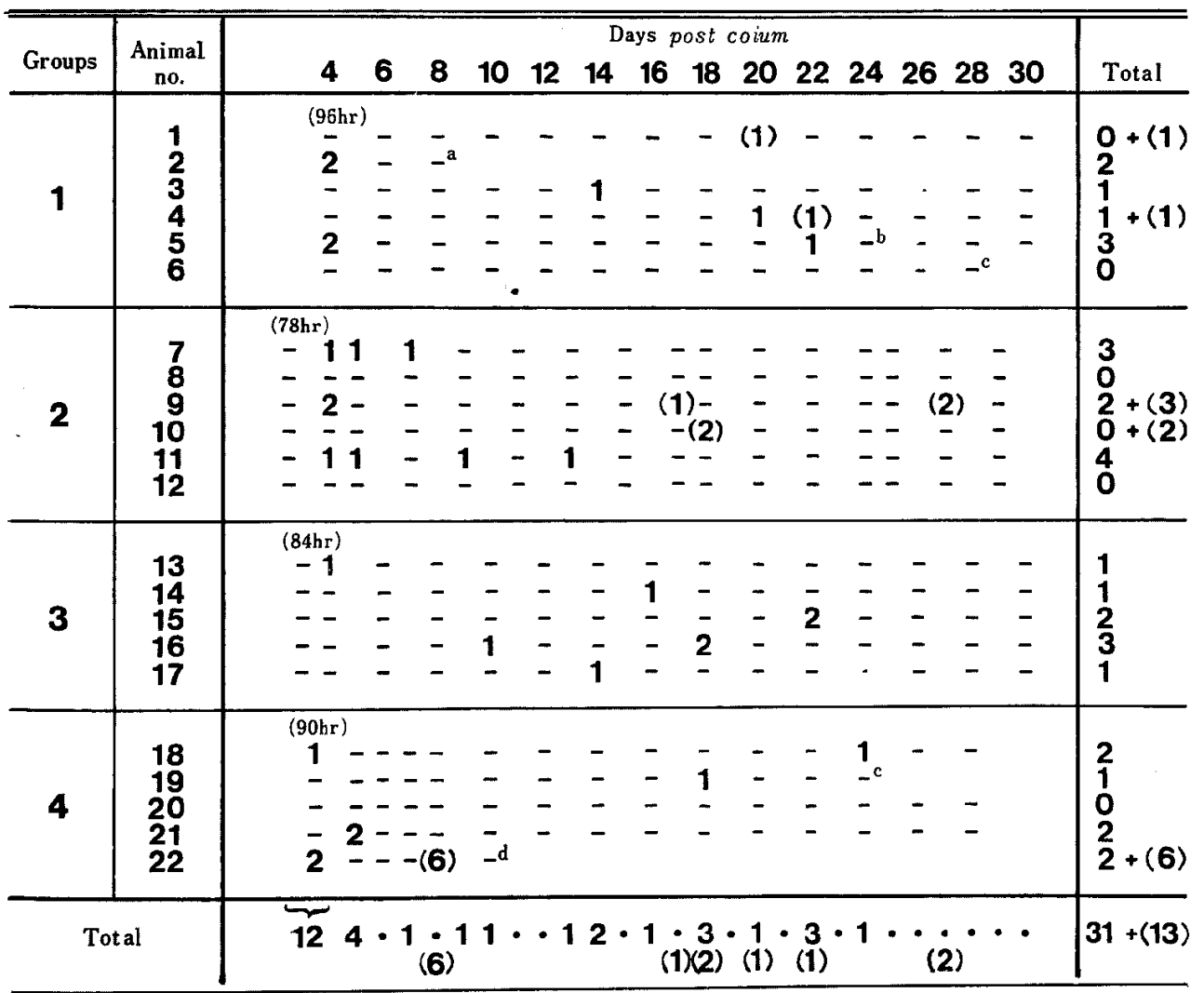

- -..... No ova recovered.

( )...... Numbers of ova suspected.

a ….. Died by accident. No ova recovered from the reproductive tract.

b..... No new ovulation confirmed by laparotomy.

c..... Autopsy. No ova recovered from the reproductive tract.

d ..... Died by accident. Five ova recovered from both uterine horns and one oviduct. Fourteen corpora lutea in the ovary. 


\section{TSUTSUMI and TAKEDA}

tion rate was seen during the period from 18 to 22 days p.c. (Table 1). There was no appreciable difference among numbers of animals in which ova were detected at 5 day intervals during the period from 6 to 25 days p.c. (Table 2).

Table 2. Number of trials of vaginal flushing and number of animals from which ova were recovered

\begin{tabular}{lccccccc}
\hline Days post coitum & $3-4$ & 5 & $6-10$ & $11-15$ & $16-20$ & $21-25$ & $26-30$ \\
\hline $\begin{array}{c}\text { Total no. of vaginal } \\
\quad \text { flushings }\end{array}$ & 22 & 11 & 64 & 46 & 60 & 46 & 47 \\
$\begin{array}{c}\text { No. of animals from which } \\
\quad \text { ova were recovered }\end{array}$ & 8 & 3 & $3(4)$ & 3 & $3(7)$ & $3(4)$ & $0(1)$ \\
$\begin{array}{c}\text { Rate of animals from which } \\
\text { ova were recovered }\end{array}$ & 36.4 & 27.3 & $4.7(6.3)$ & 6.5 & $5.0(11.7)$ & $6.5(8.7)$ & $0.0(2.1)$ \\
\hline
\end{tabular}

Figures in parentheses are the number of animals having together with ova suspected.

\section{Plate 1}

\section{Explanation of Figures}

Ova were recovered by the vaginal flushing. Diameter including the mucin layer is given for each ovum.

Fig. 1. An ovum recovered 90 hours post coitum. The vitellus shows regular fragmentation. Diameter $342 \mu$.

Fig. 2. An ovum recovered 4 days post coitum. The zona pellucida is still clear. Diameter $352 \mu$

Fig. 3. An ovum recovered 4 days post coitum. The zona pellucida has undergone a marked degenerative change. Diameter $382 \mu$.

Fig. 4. An ovum recovered 5 days post coitum. The zona pellucida has disappeared. Diameter $340 \mu$.

Fig. 5. An ovum recovered 7 days post coitum. Diameter $301 \mu$.

Fig. 6. An ovum recovered 9 days post coitum. Diameter $356 \mu$.

Fig. 7. An ovum recovered 14 days post coitum. The mucin coat has undergone a marked degenerative change. Diameter $375 \mu$

Fig. 8. An ovum recovered 16 days post coitum. Diameter $357 \mu$. Note the shrunken vitellus.

\section{Plate 2}

\section{Explanation of Figures}

Figs. 9-13 show the ova recovered by the vaginal flushing. Figs. 14 and 15 show suspected materials which were analogous to the degenerative ova. Fig. 16 shows an ovum recovered from the uterine lumen at autopsy 13 days post coitum.

Fig. 9. An ovum recovered 18 days post coitum. Diameter $294 \mu$.

Fig. 10. An ovum recovered 18 days post coitum. This ovum may have been liberated from the mucin layer. Diameter $180 \mu$.

Fig. 11. An ovum recovered 22 days post coitum. Diameter $284 \mu$.

Fig. 12. An ovum recovered 22 days post coitum. Diameter $193 \mu$.

Fig. 13. An ovum recovered 24 days post coitum. Diameter $569 \mu$.

Fig. 14. Suspected material recovered 20 days post coitum. This sphere was transparent but showed a scanty content. Diameter $181 \mu$.

Fig. 15. Suspected material recovered 27 days post coitum. Diameter $112 \mu$.

Fig. 16. A uterine ovum recovered from a pseudopregnant doe 13 days post coitum. A small sphere including the degenerative vitellus was liberated from the mucin by applying slight pressure. Diameter of the mucin coat $471 \mu$. 
Expulsion of Unfertilized Ova into Vagina

Plate 1
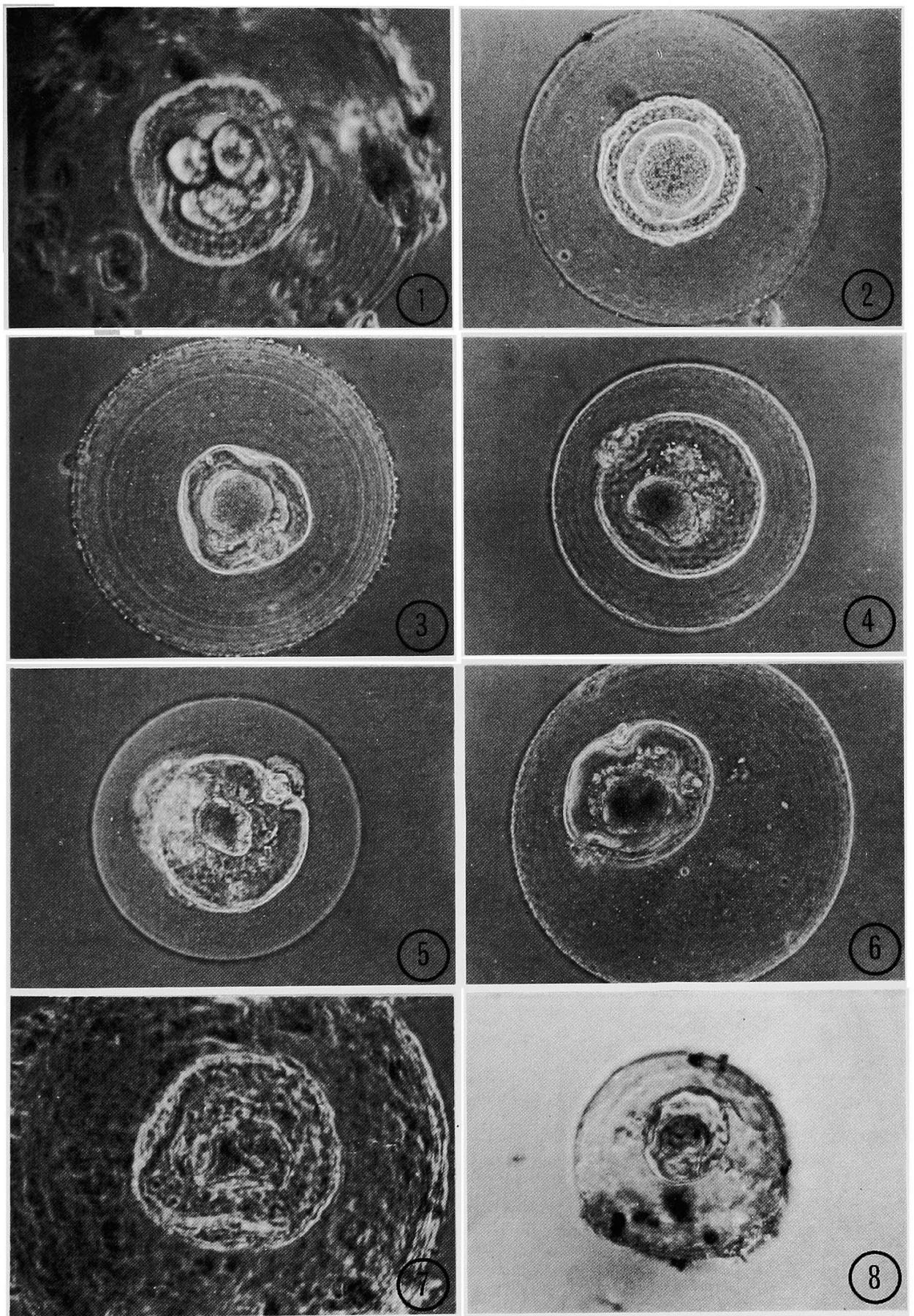
Tsursumi and Takeda

Plate 2
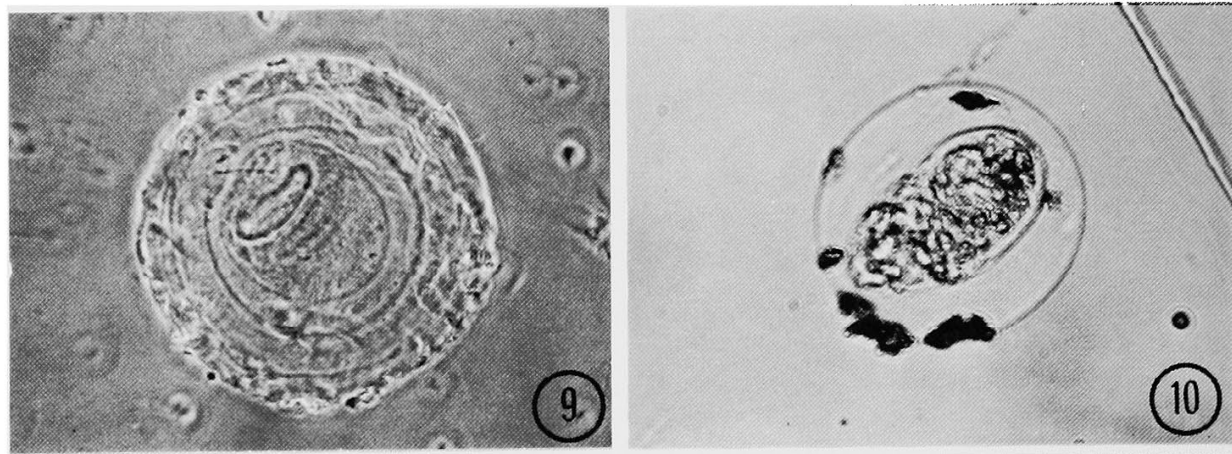

(10)
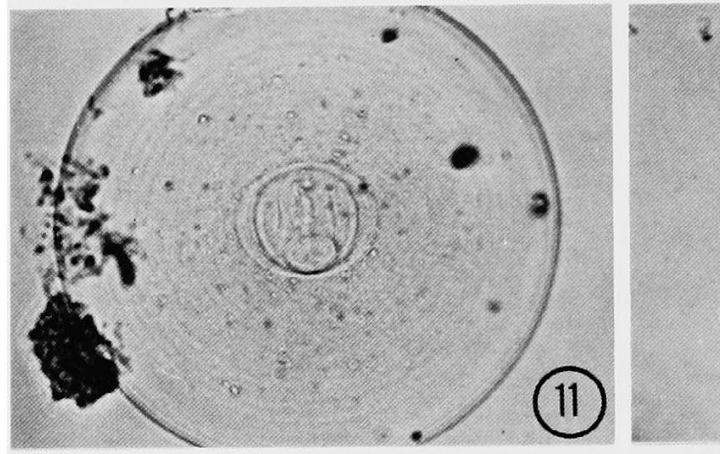

(11)

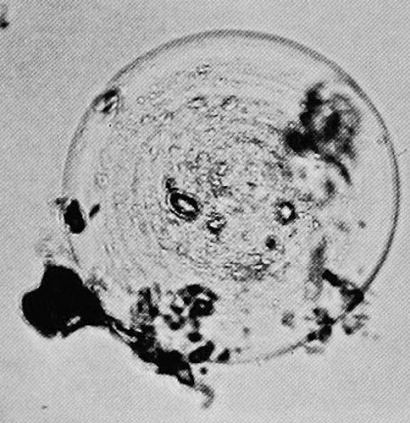

(12)
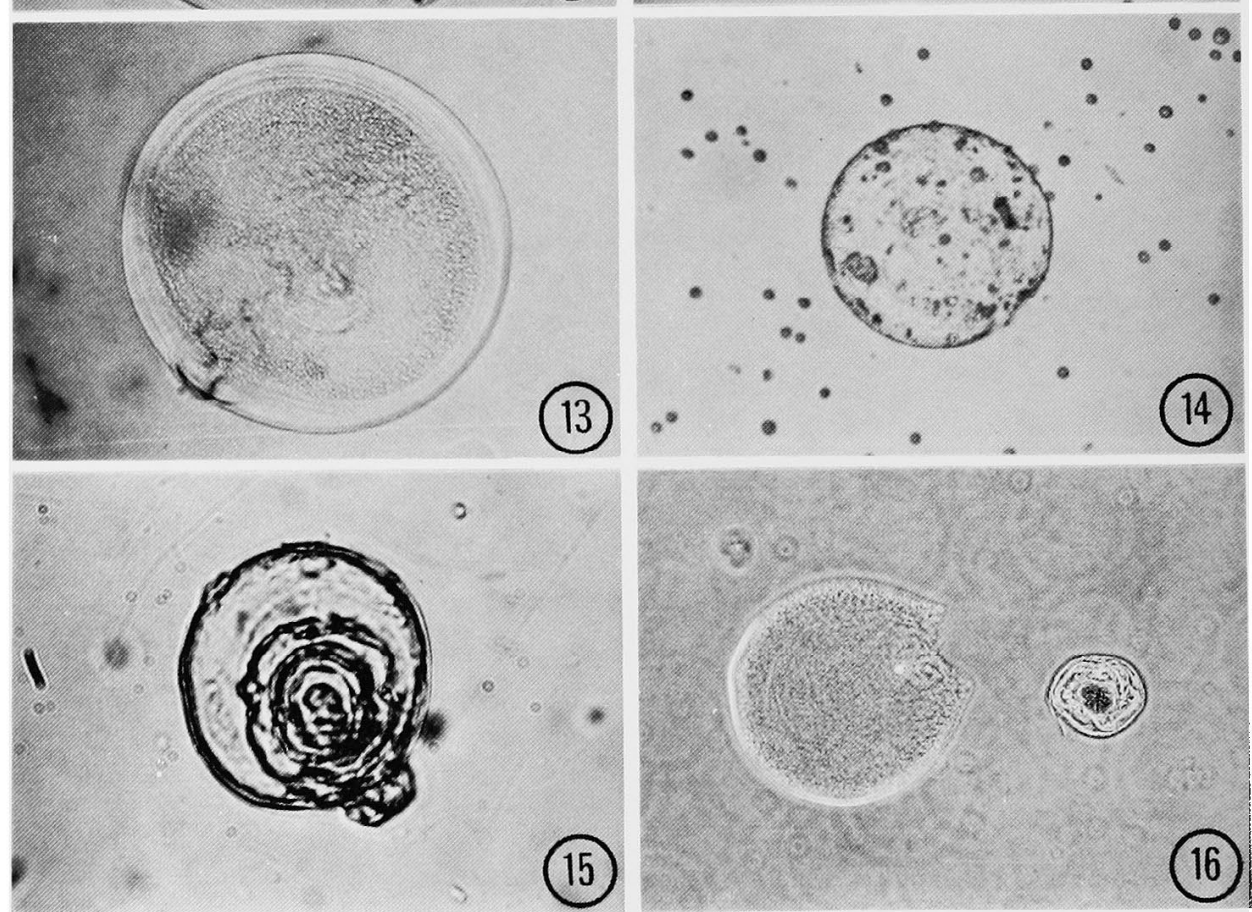


\section{Expulsion of Unfertilized Ova into Vagina}

Ova greatly varied in size and morphology. These underwent marked degenerative changes in various degrees within the same flushing and/or time of flushing. The vitellus generally presented a shrunken appearance. Very few ova were fragmented regularly (Fig. 1) or irregularly in the vitellus (Figs. 3-6). As the days of pseudopregenancy elapsed, the vitellus disintegrated and/or disappeared in some ova (Figs. 9, 11-13). The zona pellucida was clear in a half number of ova recovered 4 days p.c. (Figs. 1, 2), although degeneration was seen in the other ova (Fig. 3). After 5 days p.c. the inner side of the zona pellucida was diffused and the zona seemed to have disappeared in most of the ova. Then, the spherical bodies located within the mucin were distored or obscure in some ova. As noted by ADAMs ${ }^{1}$, application of a slight pressure on the uterine ova of 13 and 16 days p.c. in pseudopregnancy also caused liberation of the spherical bodies from the mucin in our preliminary study (Fig. 16). These liberated spherical bodies appeared in the flushings after the termination of pseudopregnant period (Figs. 10, 12). Fine concentric circular structure of the mucin coat was clear. The diameter of the ovum and thickness of the surface layers are given in Table 3. There were no significant changes accompany-

Table 3. Diameter and thickness of surface layers of the ovum recovered by the vaginal flushing during pseudopregnancy

\begin{tabular}{|c|c|c|c|c|c|c|c|c|}
\hline \multirow{2}{*}{$\begin{array}{l}\text { Period } \\
\text { (Days } \\
\text { post } \\
\text { coitum) }\end{array}$} & \multicolumn{2}{|r|}{ Outer diameter ${ }^{\mathrm{a}}$} & \multicolumn{2}{|c|}{$\begin{array}{c}\text { Inner diameter } \\
(\mu)\end{array}$} & \multicolumn{2}{|c|}{$\begin{array}{l}\text { Thickness of zona } \\
\text { pellucida }(\mu)\end{array}$} & \multicolumn{2}{|c|}{$\begin{array}{c}\text { Thickness of mucin } \\
\text { layer }(\mu)\end{array}$} \\
\hline & $\mathbf{N}$ & $\underset{\text { (Range) }}{\text { Mean } \pm S . E .}$ & $\mathrm{N}$ & $\begin{array}{l}\text { Mean } \pm S . E . \\
\text { (Range) }\end{array}$ & $\mathrm{N}$ & $\underset{\text { (Range) }}{\text { Mean } \pm S .}$ & $\mathrm{N}$ & $\begin{array}{l}\text { Mean } \pm S . E . \\
\text { (Range) }\end{array}$ \\
\hline $3 \frac{3}{4}-5$ & 15 & $335 \pm 12(233-383)$ & 15 & $163 \pm 6(105-197)$ & 7 & $3 l \pm 4(2 l-54)$ & 14 & $80 \pm 8(28-120)$ \\
\hline $6-17$ & 6 & $362 \pm 16(301-418)$ & 6 & $167 \pm 6(144-185)$ & & & 5 & $95 \pm 8(75-118)$ \\
\hline $18-30$ & & & 5 & $188 \pm 5(180-207)$ & & & & \\
\hline
\end{tabular}

a ...... Total diameter including mucin layer.

b ..... Total diameter excluding mucin layer (outer zonal diameter).

N ...... Number of ova measured.

S. E. …... Standard error.

ing the stages of pseudopregnancy in total diameter including the mucin layer (outer diameter), in the total diameter excluding the mucin layer (inner diameter), and in the thickness of the mucin layer. The thickness of the mucin layer, however, considerably varied with each ovum.

\section{Discussion}

It was confirmed in the present study that some of the uterine ova in pseudopregnant rabbits were expelled into the vagina through the cervix. The ova appeared concentrically in the vaginal lumen 4 and 5 days p.c., and the earliest recovery of ova was confirmed by the flushing at 90 hours p.c. It is well known that either fertilized or unfertilized eggs, require 72 to 80 hours to be transported to the uterus through the entire length of the oviduct. Thus, it is suggested that the ova recovered from the vagina 90 hours p.c. may require about 10 to 18 hours to pass through the uterine horn and cervix. Since a limited number of eggs were found very close to the internal ostium of the cervix at 78 hours p.c. in pregnant rabbits ${ }^{9}$, it may be noted that there is little doubt as to the rapidity of transport of ova. A question arises as to why eggs can possibly pass through the cervix at such an early period of pseudopregnancy. The evidence of the expulsion of eggs into the vagina indicates that either some blocking mechanisms of the 


\section{Tsutsumi and TAKEDA}

cervix which normally would block egg transport may not be induced by unfertilized ova, or activity of the mechanism would be very weak. In any event, the early maternal recognition of the fertilized eggs must be established prior to 90 hours p.c. Progestins and hCG-like gonadotropin in the rabbit blastocysts aged 5 and 6 days were investigated in relation to the maternal recognition of pregnancy, although these problems are still unsettled ${ }^{10 \sim 16)}$. Fuchs and BeLrNG ${ }^{17)}$ found that plasma progesterone in pregnant does commenced to rise on day 4 and was significantly higher than in pseudopregnant does on 5th to 10th day. These facts suggested that the maternal recognition of pregnancy occurs in an early preimplantation stage. Although the mechanisms of the cervix in an early pregnant stage have not been explored yet, the present results may have a contribution to the elucidation of this problem.

The vaginal flushings were continued until about 30 days p.c., because the effects of the pseudopregnancy on the uterine mucosa and on the vaginal mucus extended beyond and over the period of pseudopregnancy ${ }^{5,18}$. Although the ova appeared dispersedly after 6 days $p . c$., the recovery rate of the ova was higher on 18 th to 22 nd day p.c. In most of the does, the fluid flushed from the vagina was cloudy during this period. This is due to the flow of uterine mucus into the vagina, which occurs at the end of pseudopregnancy ${ }^{18}$.

In general, a very low recovery rate of the ova may be related with the time of retention of ova in the vaginal lumen. The time required for the discharge of the ova from the vagina is still unknown. The vaginal flushings, however, showed an $81 \%$ average recovery rate in the preliminary trials when known number of Sephadex particles were deposited at the proximal portion of the vaginal lumen and the flushing was made after $5 \mathrm{~min}$. Therefore, the ova recovered in the present study would be only a part of the ova expelled from the uterus into the vagina.

The most probable size of the full-grown rabbit ovum was estimated to be $120-130 \mu$ in diameter by HARTMAN ${ }^{19)}$, and the diameters of two fertilized unsegmented ova were 0.172 and $0.176 \mathrm{~mm}$ according to GrEGoRY ${ }^{20}$ ). The diameters of the uterine unfertilized ova including zona pellucida were 133 to $168 \mu 90$ to 150 hours $p . c^{21)}$, and these figures corresponded with the inner diameters of the ova recovered from the vagina in the present study. HASHImoro ${ }^{21)}$ described that the zona of the uterine ovum 90 to 150 hours $p$.c. showed a slight swelling (28-37 $\mu$ in width), while no change was reported by TAKEISH et al. ${ }^{22)}$ Although the zona of the vaginal ovum became unmeasurable due to disappearance of the inner side on and after 5 days p.c., the thickness of the zona of the vaginal ovum 4 days p.c. was the same as that of the uterine ovum. The average thickness of the mucin coats of the uterine ova decreased from $98 \mu 130$ hours p.c. to $50 \mu 150$ hours p.c. in observations made by HaSHIMOTO21). However, the thickness of the mucin coats of the vaginal ova greatly varied individually in the present study, anp the variation found in the total diameters including mucin layer of the vaginal ova depended on the thickness of the mucin layer.

In general morphology, the vaginal ova were the same as the uterine ova as described by ADAMS ${ }^{1)}$, except that degeneration was more advanced.

\section{References}

1) Adams, C. E., J Reprod Fert 23: 319-324. 1970.

2) Tsutsumi, Y., Y. Tamura, and K. Miyamoto, J Facul Agric Hokkaido Univ 58: 262-270. 1975.

3) ORsini, M. W., J Reprod Fert 3: 283-287. 1962.

4) Howe, G R., J Reprod Fert 21: 339-341. 1970.

5) Tsutsumi, Y., and E.S. E. Hafez, J Morph 118: 43-56. 1966.

6) Noyes, R. W., C.E. Adams, and A. Walton, J Endocr 18: 108-117. 1959.

7) Adams, C. E., J Endocr 31: xxix-xxx. 1965. 
8) Adams, C. E., In Preimplantation stages of pregnancy G. E. W. Wolstenholme and M. O'ConNor eds Churchill. London. 1967.

9) Tsutsumi, Y., and E.S. E. Hafez, J Morph 144: 323-336. 1974.

10) Huff, R. L., and K. B. Erk-Nes, J Reprod Fert 11: 57-63. 1966.

11) Seamark, R.F., and C. Lutwak-Mann, J Reprod Fert 29: 147-148. 1972.

12) Fujimoto, S., H. D. Woody, and W. R. Dukelow, Fed Proc 32: 214. 1973.

13) Haour, F., and B. B. Saxena, Science 185: 444-445. 1974.

14) Holt, J. A., S. M. Wilson, and P. L. Keyes, Fed Proc 34: 323. 1975.

15) Fujimoto, S., J.S. Euker, G. D. Riegle, and W. R. Dukelow, Proc Japan Acad 51: 123-125. 1975.

16) Sundaram, K., K. G. Connell, and T. Passantino, Nature Lond 256: 739-741. 1975.

17) Fuchs, A.-R., and C. Beling, Endocrinology 95: 1054-1058. 1974.

18) Tsutsum, Y., and Y. НAchinohe, Jap J Zootech Sci 39: 12-19. 1968.

19) Hartman, C. C., Quar Rev Biol 4: 373-388. 1929.

20) Gregory, P.W., Contr Embryol 21: 141-168. 1930.

21) Hashimoto, K., Bull Exp Biol Jap 8: 124-132. 1958.

22) Takeishi, M., T. Ouchi, K. Ichihara, T. Tsunekane, and A. Sugawa, Bull Coll Agr \& Vet Med Nihon Univ 16: 28-35. 1963.

\title{
偽妊娠家兔未受精卵の腟への排出
}

\author{
堤 義雄・武田哲男
}

北海道大学農学部, 札幌市 060

偽娃娠家兔の未受精卵の運命はまだ明らかにされてい ない。しかし偽好娠 17 日目の子宮内にはをだ少数の卵 子が認められ，また偽好娠 4 日目の子宮内卵子数が妊娠 時に比較して減少していることが知られてきた.この事 は子宮内末受精卵の一部が偽娃娠早期に腟へ移動してい ることを示唆する.そこで本研究では不妊性交配後約 1 か月間, 隔日に胵洗條を行い, 腔内に排出されていると 思われる未受精卵の採取を試みた. 22 羽の成熟雉家鬼に つき合計 307 回の胵洗滌で, 退化未受精卵 31 個と卵子 由来と思われるもの 13 個が得られ，偽妊娠期に未受精
卵の一部が明らかに胵に排出されていることが証明され た.このうち最初に採取された卵子は交配後 90 時間目 のものであった．实験の全期間を通じて得られた卵子の 約 52\%は偽妊娠 5 日目までの間に集中して出現した. その後, 偽妊娠期間を越えても長期にわたり散発的に採 取されたが，特に不妊性交配後 18-22 日に多い傾向がみ られた．以上のことから，俘妊娠家鬼の子宮内卵子は一 度に胵へ排出されているのではなく，長期間にわたり徐 タに排出されているものと考えられる。 